\title{
Correction: anorectal malformations
}

\author{
Marc A Levitt ${ }^{*}$ and Alberto Peña
}

\section{Correction}

After the publication of this work [1] it was brought to the authors attention that Figure five (Figure 1 here) contained a duplication error in the PDF format, where it featured a perianal fistula instead of a rectovestibular fistula in females. The correct figure is given below:

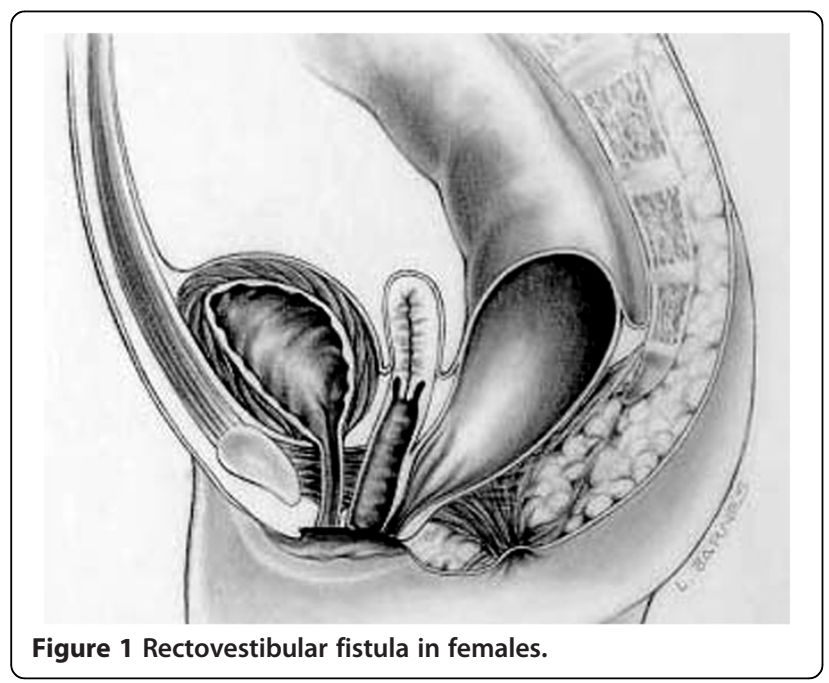

We regret any inconvenience that this inaccuracy may have caused.

Received: 13 December 2012 Accepted: 13 December 2012

Published: 15 December 2012

\section{References}

1. Levitt MA, Alberto P: Anorectal malformations. Orphanet J Rare Dis 2007, 2:33.

\section{Submit your next manuscript to BioMed Central and take full advantage of:}

- Convenient online submission

- Thorough peer review

- No space constraints or color figure charges

- Immediate publication on acceptance

- Inclusion in PubMed, CAS, Scopus and Google Scholar

- Research which is freely available for redistribution

Submit your manuscript at

www.biomedcentral.com/submit

( Biomed Central

\footnotetext{
Department of Pediatric Surgery, Cincinnati Children's Hospital, University of
}

* Correspondence: marc.levitt@cchmc.org Cincinnati, Cincinnati, Ohio45229, USA 